\title{
"Prerequisites for the creation of financial and credit infrastructure of support for agricultural enterprises in Ukraine"
}

\author{
Kateryna Andriushchenko iD https://orcid.org/0000-0002-6274-5310 \\ R https://publons.com/researcher/1488722/kateryna-andriushchenko/ \\ Mykola Ishchenko iD https://orcid.org/0000-0002-6820-9455 \\ Mykhailo Sahaidak iD https://orcid.org/0000-0001-6526-1170 \\ AUTHORS \\ R http://www.researcherid.com/rid/E-7777-2018 \\ Mariia Tepliuk (D https://orcid.org/0000-0001-6823-336X \\ R http://www.researcherid.com/rid/K-4029-2018 \\ Oksana Domina iD https://orcid.org/0000-0003-4242-6344 \\ R http://www.researcherid.com/rid/L-2292-2018
}

Kateryna Andriushchenko, Mykola Ishchenko, Mykhailo Sahaidak, Mariia Tepliuk ARTICLE INFO and Oksana Domina (2019). Prerequisites for the creation of financial and credit infrastructure of support for agricultural enterprises in Ukraine. Banks and Bank Systems, 14(2), 63-75. doi:10.21511/bbs.14(2).2019.06

DOI http://dx.doi.org/10.21511/bbs.14(2).2019.06

RELEASED ON Wednesday, 29 May 2019

RECEIVED ON Saturday, 27 October 2018

ACCEPTED ON Wednesday, 08 May 2019

\section{(cc) EY}

LICENSE

This work is licensed under a Creative Commons Attribution 4.0 International License

JOURNAL "Banks and Bank Systems"

ISSN PRINT 1816-7403

ISSN ONLINE 1991-7074

PUBLISHER LLC "Consulting Publishing Company "Business Perspectives"

FOUNDER

LLC "Consulting Publishing Company "Business Perspectives"

NUMBER OF REFERENCES

35
NUMBER OF FIGURES

3
NUMBER OF TABLES

3

(C) The author(s) 2023. This publication is an open access article. 


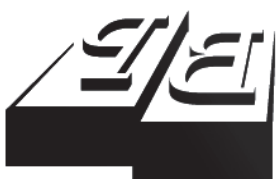

BUSINESS PERSPECTIVES

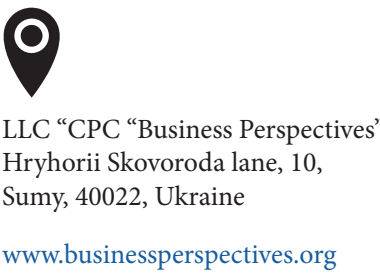

Received on: $27^{\text {th }}$ of October, 2018 Accepted on: $8^{\text {th }}$ of May, 2019

(C) Kateryna Andriushchenko, Mykola Ishchenko, Mykhailo Sahaidak, Mariia Tepliuk, Oksana Domina, 2019

Kateryna Andriushchenko, Doctor of Economics, Associate Professor, Professor, Department of Economics and Entrepreneurship, Kyiv National Economic University named after Vadym Hetman, Ukraine.

Mykola Ishchenko, Doctor of Economics, Professor, Department of Accounting, Taxation, Public Management and Administration, Kryvyi Rih National University, Ukraine.

Mykhailo Sahaidak, Doctor of Economics, Associate Professor, Professor, Department of Economics and Entrepreneurship, Kyiv National Economic University named after Vadym Hetman, Ukraine.

Mariia Tepliuk, Ph.D. in Economics, Senior Lecturer, Department of Economics and Entrepreneurship, Kyiv National Economic University named after Vadym Hetman, Ukraine.

Oksana Domina, Ph.D. in Economics, Assistant, Department of International Economics and Marketing, Taras Shevchenko National University of Kyiv, Ukraine.

\section{(ㄷ) (1)}

This is an Open Access article, distributed under the terms of the Creative Commons Attribution 4.0 International license, which permits unrestricted re-use, distribution, and reproduction in any medium, provided the original work is properly cited.
Kateryna Andriushchenko (Ukraine), Mykola Ishchenko (Ukraine), Mykhailo Sahaidak (Ukraine), Mariia Tepliuk (Ukraine), Oksana Domina (Ukraine)

\section{PREREQUISITES FOR}

THE CREATION OF FINANCIAL

AND CREDIT INFRASTRUCTURE OF SUPPORT FOR AGRICULTURAL ENTERPRISES IN UKRAINE

\begin{abstract}
The study analyzed and summarized publications on the nature of the formation of financial and credit infrastructure, which is created in order to support agricultural enterprises. The functioning and development of financial and credit infrastructure as a factor of social and economic development of the country is explored. The features of diversification of financing sources of agricultural enterprises are determined. The role of bank lending to agricultural enterprises in Ukraine is investigated. The model of interaction of participants of the financial and credit infrastructure of support for agricultural enterprises through the formation of the certain conditions is proposed. It is proved that such measures will provide increase in the efficient use of available agro-resource potential and reopen the industry attractiveness for investing companies.
\end{abstract}

\section{Keywords \\ financing, diversification, agricultural credit, insurance, tax incentives, agro-leasing}

JEL Classification G21, G23, G24, Q13, Q14

\section{INTRODUCTION}

The unevenness of the demand and supply of product preferences of the population around the world, the increase in the cost of agricultural production necessitate the companies to attract investment for the development and purchase of modern technology, fertilizers, the introduction of new varieties of plants, the construction of greenhouse complexes, etc.

According to experts, by 2050 , demand for food is predicted to increase by $70 \%$ around the world, and for its satisfaction it is necessary to invest in agricultural enterprises not less than 80 billion US dollars (Willer \& Kilcher, 2009). It should be noted that state institutions in developing countries form a disproportionately low share of agricultural loan portfolios, compared to the share of agriculture in the structure of GDP (World Economic Forum, 2018).

Creation of favorable conditions for stable financial support of agricultural enterprises is possible only at the appropriate level of development of financial and credit infrastructure, which envisages improvement of mechanisms for its functioning, interaction of subsystems and elements, distribution and use of financial and credit resources. In Ukraine, a large number of agricultural enterprises have losses, 
they are not creditworthy. This does not allow them to carry out expanded reproduction and modernization on the basis of innovations, without which it is impossible to produce competitive products under current conditions.

The period of structural and system changes has created additional problems for a number of countries, especially in those cases where fragmented ownership structures prevented the creation of viable agricultural co-operatives (Andriushchenko et al., 2018; Andriushchenko, Shergina, \& Kovtun, 2018).

\section{THEORETICAL BASIS}

First of all, you should decide on the very concept of "financial and credit infrastructure". There are interpretations of the financial and credit infrastructure, which cannot be considered sufficiently capacious in accordance with the specifics of support of agricultural enterprises. For example, the financial and credit infrastructure of the agro-industrial complex can be interpreted as an open transforming system, whose level and directions of development are directly dependent on the existing economic system (Stukach, 2007). The aforementioned definition does not disclose the purpose, structure and functions of the financial and credit infrastructure of support for agricultural enterprises, giving only general features, inherent to many systems.

According to another definition, the financial and credit infrastructure of support of the agro-industrial complex is a complex whose entities accumulate and distribute financial and credit resources, form and move capital between the various market participants in the agro-industrial complex to ensure the continuity of agricultural production (Yaron, 1994).

There is a definition, which interprets the credit and financial infrastructure of the agro-industrial complex as a set of institutions (credit and banking institutions, stock exchanges, financial, investment and insurance companies) operating within the monetary, stock, and investment markets and performing functions of ensuring the standard mode of their functioning (Kovyrshin, 2010; Mitrofanova, 2016). In this definition, just as in the previous one, there is no focus on the financial and credit infrastructure of support for agricultural enterprises in the context of the normal functioning of agriculture, and not of financial markets. Dusuki (2008) points out that the finan- cial and credit infrastructure of the agro-industrial complex is a means of regulating the aggregate of financial and credit relations that mediate vertical and horizontal economic relations, and economic relations between the state (institutional sphere) and economic entities of the industry in order to ensure food security of the country (Dusuki, 2008). One of the important disadvantages of this definition is the lack of directions and economic conditions that are necessary for creating a financial and credit mechanism to ensure bringing in proportions, structure and composition of its tools.

Menkyu (2013) understands the financial and credit infrastructure as a set of economic institutions (financial securities markets, banks, mutual funds (share funds), pension funds, credit unions, insurance companies, etc.), which help to direct resources of individuals wishing to make savings, to those who need borrowed capital in the form of investment. In other works, the term "financial and credit infrastructure of agricultural enterprises" includes a set of institutions (credit institutions, stock exchanges, financial and insurance companies) operating within the monetary, stock and investment markets and performing functions to ensure the normal mode of their functioning and the entire regional complex (Häring et al., 2009; Pleshakova \& Drobyishev, 2005). Here is a link to the regional complex, but not specifically to support agricultural enterprises, and the list of institutions of financial and credit infrastructure is not complete.

Ukrainian researchers represent financial and credit infrastructure as a set of interconnected and interacting financial institutions, directly involved in financial activities and contributing to its implementation, mediating economic relations, that is, associated with the movement of cash flows. In this study, it is proposed to consider the 
Finance is an economic category that reflects economic relations in the process of creating and distributing funds of funds.

Financial infrastructure is a set of institutions and elements that create favorable conditions for the functioning of the entire financial system (financial management system, regulatory and legislative framework, financial market infrastructure).
Credits are the means and material values provided by the creditor for use by the borrower for a specified period and at a percentage.

Credit infrastructure is a collection of cash and tangible assets provided by a creditor for use by the borrower for a specified period and at a percentage, the use of which ensures satisfaction of the social reproduction needs.

Financial and credit infrastructure is a set of interconnected financial and credit organizations that mediate financial and credit relations in regards to the movement of incoming and outgoing cash flows in the process of capital turnover of agricultural enterprises.

Figure 1. Essential characteristic of the concept of financial and credit infrastructure of agricultural enterprises

financial and credit infrastructure in such a way as it is presented in Figure 1.

The urgent necessity for financial and credit infrastructure in order to support the agricultural enterprises as an integral part of the overall social and economic infrastructure is also noted in various works. Thus, it is indicated that the relation to the accumulation of debt, as well as readiness to assume responsibility, or to offer land as collateral, are closely related to the cultural values and convictions of each country (OECD, 2001; Schinasi, 2005; Shwedel, 2007). They affect the speed and efficiency at which the institutions and processes develop, which are necessary for development of the financial markets. There are great number of successful business models of financial and credit infrastructure directed at supporting agricultural enterprises (OECD, 2001; World Bank, 2002).

Tanklevska (2011) summarizes the experience of legal provision of agricultural policy in the USA and the EU in the context of the need to update the institutional framework of the state agricultural policy in Ukraine. The author also proposes directions for adapting its legal support to EU practice, which are designed for a certain period of effect, by defining the conditions, order and volume of funding for government programs, where their approval is preceded by extensive public discussion with the participation of scientists and all parties concerned.

Marangu (2007) defines the best of the investigated variants of financing of various organizational and legal agricultural associations, peculiarities of their development, advantages and disadvantages of integration agrarian formations. The author also summarized the prospects of further development of the most widespread forms of integrated agro-industrial structures.

Studies have shown that in countries where labor productivity of the agricultural enterprises has increased, reforms and innovative changes in financial and credit infrastructure, as well as involvement of leasing and forward contracts have taken place (Mathijs \& Swinnen, 1999).

In a number of works (Mitrofanova, 2010; Willer \& Kilcher, 2009; Yaron, 1994), the peculiarities of state regulation are revealed through the mechanisms of taxation of the agrarian sector enterprises, a thorough analysis and identification of the problems of applying special taxation regimes of agricultural enterprises, the added value tax of economic entities of this branch, a fixed agricultural tax and its replacement for a single tax are 
made, and also disadvantages of tax innovations in agriculture are justified.

Häring et al. (2009), Kuznets (1961), and Myint (2007) examine the problematic aspects of tax regulation of agricultural sphere in Ukraine, monitor existing problems in the light of the realities of the modern economic space, identify the preconditions, and propose to reform the Ukrainian taxation system by creating real conditions for the transition of the agricultural sphere to an investment-innovative model of development based on the macroeconomic balance of the three components, namely the needs of the state, the ability of payers and the optimization of macro structural proportions.

Myint (2007) considers the example of Myanmar, where agribusiness retailers are involved in forming the internal structure of the main elements of the agricultural added value chain, offering deferred payments to small farmers.

Marangu (2007) examines the typical case of forming the external structure of key elements of the added value chain in Kenya, where small fruit and vegetable producers are able to access bank financing for acquiring agrochemicals through export contracts. The exporter pays the farmers through the bank, which takes the planned payment of the loan and money comes directly to the farmer.

Financing the chain of added value creates an opportunity to expand the solvency of agricultural enterprises, increasing their performance through repayment of funding, and consolidation of the interrelation among the chain participants. The specific possibilities that contribute to the financing of the added value chain are determined by the context and the business model by determining the role of each participant in this chain. Campion (2006) pointed out that financing is better viewed through the chain of creation of the added value, because through it, it is possible to identify all the specific features and bottlenecks rather than if viewed through financial institutions.

Nyoro (2007) focuses on the variability of nature in Africa, as well as on the motives that influence the formation of structural elements that are part of the financial and credit infrastructure of support for agricultural enterprises, and are mainly aimed at the desire to expand distribution markets rather than at efficiency and availability of funding. For example, traders are usually used as a tool for purchasing, while international experience suggests that agricultural enterprises use them as part of a strategy to stimulate sales of agricultural products. For financial institutions, Nyoro (2007) proposes an approach to reducing the risks and costs of providing financial services. For agricultural enterprises, the aforementioned mechanism is proposed for obtaining financing, which may be inaccessible due to lack of collateral or high transaction costs of credit security.

Despite changes in agriculture and agribusiness, most of the typical financial product proposals for agricultural enterprises are ineffective and not innovative. Financial intermediaries have lacked understanding of the specifics of the work of agricultural enterprises before, and some producers lacked financial literacy to obtain sufficient funding. The usual thinking of a financial intermediary is that the agricultural sector is too costly and risky for lending. However, large banks in this sector, such as Rabobank and Banorte, major financial institutions in the Netherlands and Mexico, suggest that agricultural loans are profiled if manufacturers are well integrated into a viable added value chain (Shwedel, 2007; Martínez, 2006).

In Kenya, Mrema (2007) notes that the accepted approach to lending to agricultural enterprises is based on a change in scientific thought in the terms "you" to "we" and focusing on the consensus of resource use and product creation. Consequently, the relationship between elements, structure, and overall state of the whole chain becomes much more important than ever before. Non-commercial, independent farmers, traders and enterprises involved in financial and credit infrastructure become working competitive partners of the same chain for survival and prosperity.

Gonzalez-Vega (2007) raises a number of questions that the transformation and consolidation of all elements of the financial and credit infrastructure of support for agricultural enterprises must meet a number of requirements. 
Table 1. Loans issued to non-financial corporations, by types of economic activity and maturities (balances at the end of 2018)

\begin{tabular}{|c|c|c|c|c|c|c|c|}
\hline \multirow{2}{*}{$\begin{array}{c}\text { Type of economic } \\
\text { activity }\end{array}$} & \multicolumn{2}{|c|}{ Total } & \multicolumn{3}{|c|}{ Including the terms } & \multicolumn{2}{|c|}{ By types of currencies } \\
\hline & UAH mln & $\%$ & Up to 1 year & $\begin{array}{l}\text { From } 1 \text { to } 5 \\
\text { years old }\end{array}$ & $\begin{array}{c}\text { More than } 5 \\
\text { years }\end{array}$ & National & Foreign \\
\hline Total provided & 841,973 & 100.0 & 419,442 & 308,405 & 114,126 & 341,574 & 500,399 \\
\hline $\begin{array}{l}\text { Agriculture, forestry and } \\
\text { fisheries }\end{array}$ & 50,469 & 6.0 & 22,658 & 21,582 & 6,229 & 28,814 & 21,655 \\
\hline Total overdue & 187,576 & 100.0 & 85,082 & 76,673 & 25,821 & 34,808 & 152,768 \\
\hline $\begin{array}{l}\text { Agriculture, forestry and } \\
\text { fisheries }\end{array}$ & 6,675 & 3.6 & 4,085 & 2,270 & 320 & 1,933 & 4,742 \\
\hline
\end{tabular}

Shwedel (2007) states that the formation of financial and credit infrastructure requires the banker to see and understand business in general. This requires adaptation to new market conditions, more accurate pricing, better understanding of risk and, consequently, high readiness to take risks (Shwedel, 2007). In his work, as a source of value, a specialist from Rabobank Mexico emphasized that with a holistic understanding of the structural elements of financial and credit infrastructure, there is a risk reduction potential based on obtaining system knowledge.

While applying the term "financial and credit infrastructure", its elements should be considered. According to the specific purpose, financial and credit infrastructure as a holistic system is divided into subsystems. The specificity of forming elements of the financial and credit infrastructure of support for agricultural enterprises determines the existence of its basic subsystems, in particular: financial and credit. The credit subsystem of financial and credit infrastructure of support for agricultural enterprises can overcome the une- ven distribution of financial resources during the year in seasonality due to the agricultural production cyclicality (Devisy, 2017). The credit subsystem includes lending by banks, financial organizations, agro-leasing. For example, in Ukraine, UAH 54 million was allocated through the NAC "UkrAgroLeasing" for the purchase of equipment, UAH 25.6 million providing loans to farms (Zelisko, 2017).

In the system of financial support of agrarian production of agricultural enterprises, bank lending provides $25-26 \%$ of financial resources and ranks second after internal self-financing (Table 1).

The conditions of the major credit programs of Ukrainian banks for agricultural enterprises are considered in Table 2.

It should also be pointed out that agricultural production has specific features that substantially distinguish it from all other types of economic activity. The main specificity is that agricultural production is associated with biological and natu-

Table 2. Conditions of the main credit programs of Ukrainian banks for agricultural enterprises, at the end of 2018

\begin{tabular}{|c|c|c|c|c|c|}
\hline \multirow{2}{*}{ Parameters } & \multicolumn{3}{|c|}{ Replenishment of working capital } & \multirow{2}{*}{$\begin{array}{l}\text { Implementation of } \\
\text { investment projects }\end{array}$} & \multirow{2}{*}{$\begin{array}{c}\text { Purchase of } \\
\text { agricultural } \\
\text { machinery }\end{array}$} \\
\hline & Overdraft & Credit limit & Term loan & & \\
\hline Amount, UAH & $\begin{array}{l}\text { Limit } \\
30-40 \%\end{array}$ & Up to 500 ths & 10 ths to $30 \mathrm{mln}$ & 50 ths $-50 \mathrm{mln}$ & $\begin{array}{c}\text { Up to } 75 \% \text { of market } \\
\text { value, } \\
50 \text { ths }-50 \mathrm{mln}\end{array}$ \\
\hline Term & 1 day -1 month & Up to 1 year & 1 day -3 years & 1 month -5 years & 1 month -5 years \\
\hline $\begin{array}{l}\text { Interest rate, } \% \\
\text { per annum }\end{array}$ & $26-28$ & $30-34$ & $22-32$ & $19-26$ & $\begin{array}{l}21-29 \text { (special } \\
\text { programs - up to } 17.0 \text { ) }\end{array}$ \\
\hline Commission, \% & 1.0 single & $\begin{array}{c}\text { 0.9-monthly and } \\
\text { up to } 3.0-\text { for each } \\
\text { transfer }\end{array}$ & $\begin{array}{l}\text { 0-1-time and/or } \\
\text { 0.1-0.5-monthly }\end{array}$ & 0.5-1.0 times & 0.5-1.0 times \\
\hline Providing & Blanket & Bail & Pledge & Pledge & Pledge \\
\hline $\begin{array}{l}\text { Insurance } \\
\text { collateral, \% }\end{array}$ & - & - & 0.3 & 0.3 & 0.3 \\
\hline
\end{tabular}


ral constituents (Willer \& Kilcher, 2009). In turn, the seasonality and cyclicality of production require the concentration of material and money resources for the periods of the year, due to the time gap between the costs incurred and the income received. The most important feature of support for agricultural enterprises, which should be taken into account by the tax system, but which is not taken into consideration by a single agricultural tax, is the seasonality of production and the time difference in the incurrence of costs and income receiving. The corresponding feature of agricultural enterprises and the inadequacy of the tax system lead to the steady accumulation of debts related to fines and penalties from agricultural producers, even taking into account their multiple write-offs and restructuring. In developed countries, agricultural enterprises pay taxes in the mode of individual income taxes - by the results of the year with an instalment payment of three months. According to the authors, such a tax regime will have a greater positive effect on the support of agricultural enterprises in Ukraine.

The system of tax incentives for the agrarian sector included an introduced from 1999 to 2015 fixed agricultural tax (now a single tax), a special regime for taxation of agricultural enterprises, which entered into force until 2017, and compensation for measures for farmers operating on a simplified system taxation (Matselioukh \& Skoryk, 2016). In accordance with the Tax Code of Ukraine, the subject of taxation of agricultural enterprises, which are included in the IV group of the single tax, is the area of agricultural land and/or lands of the water fund, owned by the agricultural producer or provided to him for use, including on the terms of the lease (Hudz', 2012).

At present, the Government of Ukraine provides agricultural producers with budget subsidies for the period from January 1, 2017 to January 1, 2022, in order somehow to support them in response to the abolition of the special regime with VAT. The funds for this were envisaged in the State Budget for 2017 (Agrarian Union of Ukraine, 2017). Insurance is the next element of the financial subsystem of the financial and credit infrastructure of agricultural enterprises. However, about this element, questions arise regarding the assignment of this sphere to any given subsystem. As the in- surance market accumulates funds that are part of the national income, in certain funds for further redistribution, one can relate this area to the financial subsystem of the financial and credit infrastructure of support for agricultural enterprises. The corresponding situation can be confirmed as follows: insurance companies pay fixed taxes and fees, resources of other organizations and individuals can and should be directed to insurance against adverse events, resources of insurance companies must be invested and generate income. On the other hand, the insurance of the characteristic properties of the loan: so the insurer transfers funds in the form of insurance premium, and then they return to the insurer at the onset of an insured accident (Arbuzov, 2011).

The next element of the credit subsystem of the financial and credit infrastructure of support for agricultural enterprises is lending through the mechanism of credit co-operation. Agricultural credit co-operation helps in solving many financial and social and economic problems facing its shareholders. The organization of credit co-operatives is aimed at accumulating funds of individual investors and creating a powerful flow of investment in agricultural production. The mechanism of agro-leasing, necessity for the development of which is due to limited financial capacity for the purchase of agricultural machinery, is also an element of the credit subsystem of financial and credit infrastructure.

\section{RESULTS}

Methodical tools of forming a financial and credit infrastructure of support for agricultural enterprises may consist of the following elements.

- Political and normative - the diagnosis of the financial position of agricultural enterprises and the elaboration of an action program for the reform of state policy and regulatory documents, which will ensure the creation of favorable conditions for the mobilization of financing. Examples: lending quotas, interest rates, bank expansion rules, prudential regulations affecting lending to agricultural enterprises, alternative dispute resolution mechanisms. When establishing the institu- 
tional framework, effective legislation is the first priority to establish reliable basic rules for the development of financial and credit infrastructure of support for agricultural enterprises. Ownership, especially with regard to the land use, is of particular importance for the development of agriculture. When using land as collateral for a loan repayment, the number of investments can be increased, and credit constraints may be weakened. Thus, the availability of legal bases for the use of land as collateral is an important basis for access to agricultural loans and financial instruments.

- Agricultural insurance - government's strategy to promote agricultural insurance, as well as to develop effective insurance products, for example, financial incentives, subsidies, etc.

- Institutional (strengthening state institutions) reforming and creating potential of state financial institutions, developing commodity exchanges, etc. This program is aimed at increasing the efficiency of the mechanisms and changing the rules of integration of agricultural enterprises into the financial system of their country. An example is the guarantee of partial coverage of risks. One more aspect of strengthening state institutions is related to the implementation of contracts. It can enforce contracts through timely and fair disclosure of non-compliance with contractual obligations or other abuses by suppliers, creditors or borrowers. This element of strengthening state institutions is necessary to allow the financial and credit sector to develop effectively, as sources of information for creditors - creation of credit histories, for borrowers - obtaining market information about offers and prices.

- Innovativeness (developing innovative products) - development of a wide range of technical assistance instruments within the framework of lending projects, for example: financing of the added value chain, financing of the treasury, guarantees for covering a partial loan for agricultural enterprises, corresponding grants, harvest insurance, agricultural hedging instruments. The development of mobile banking and payment platforms to expand access to finance and reduce transaction costs within the framework of the formation of the ecosystem. Development of the solutions to minimize systemic risks (for example, industrial and natural by means of insurance and price hedging instruments).

- Development management (knowledge management and creating the practitioners' community)-informing about own research in the knowledge production, consisting of internal level (community of practices and curricula) and external level (global and regional information dissemination activities) (Andriushchenko, Shergina, \& Kovtun, 2018). An example is the organization of two communities of practitioners: one for financing agricultural enterprises and insurance, and another for financial agricultural cooperatives.

Sustained macroeconomic programs also contribute to attracting FDI, which can become an important source of attracting an indispensable loan, as well as providing access to markets. Macroeconomic stability strengthens investor reliance by facilitating risk assessment for lenders. In those economies in transition, where macroeconomic stability has been reached by developing financial and credit infrastructure of financial markets, they are developed (OECD, 2001). In cases where the financial and credit infrastructure develops slowly, agricultural enterprises are dependent on government loans on preferential terms.

In order to meet the specific needs of some borrowers, especially in transitional periods when the financial and banking sectors are being reformed, alternative approaches to providing agricultural loans can bring significant benefits. One of these alternatives is the appeal to producers or suppliers of materials, as well as to processors and retailers as sources of financing and/or supplies of raw materials. These sources are closely linked throughout the whole chain of financial and credit infrastructure support for agricultural enterprises.

The consolidation of agricultural enterprises into credit cooperatives offers many advantages, such as proximity to customers, integration into the 
FINANCIAL AND CREDIT INFRASTRUCTURE SUPPORT FOR AGRICULTURAL ENTERPRISES

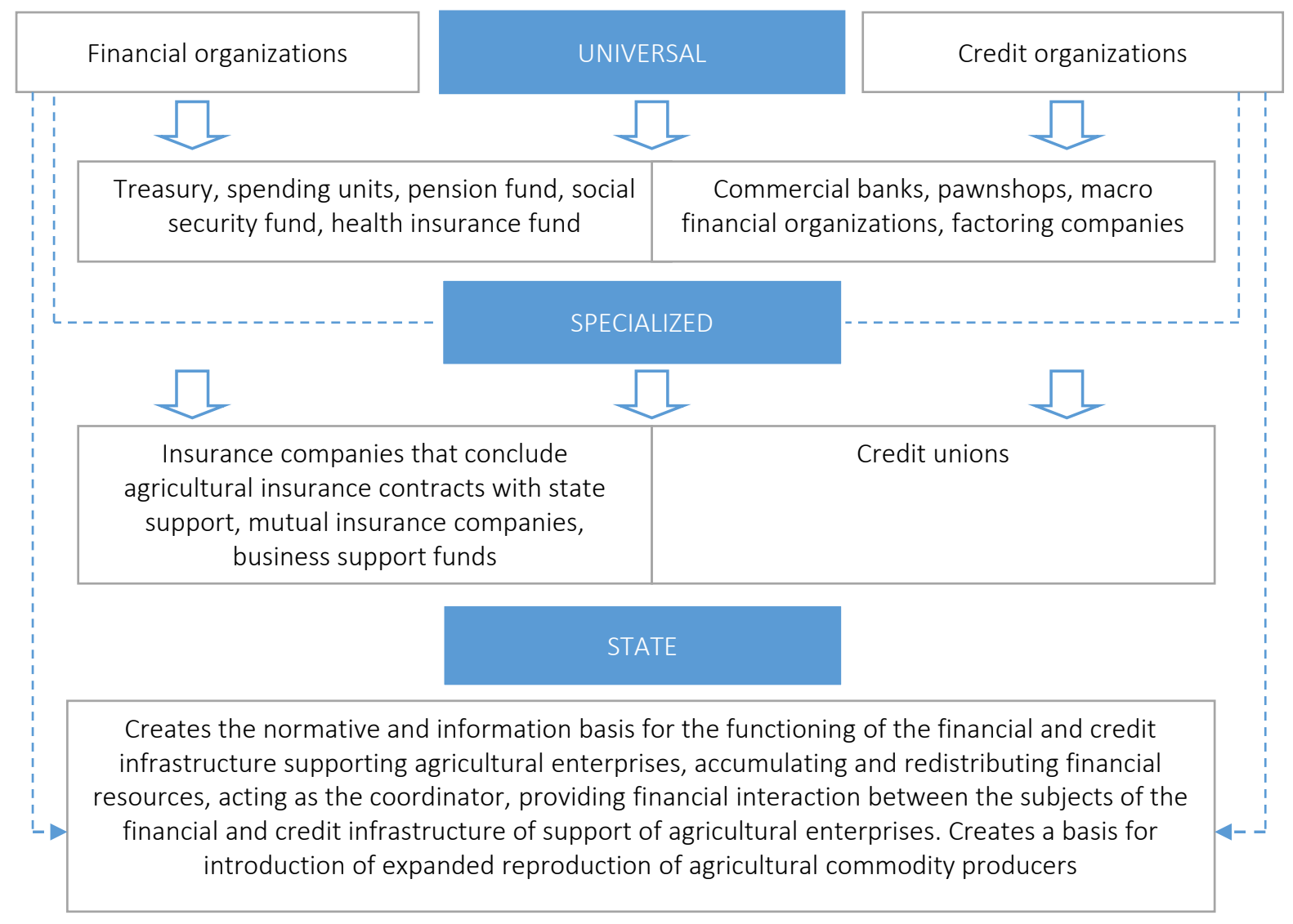

Figure 2. The institutional functioning mechanism of the financial and credit infrastructure of support for agricultural enterprises

local community and knowledge of local conditions. They tend to adapt to changing needs. The effectiveness of this association is strengthened by the competitive pressure. In the OECD countries, there are many models of cooperative banking services. One of the main strategic benefits is focusing on financial and credit operations and not on diversification of supply and marketing, thereby avoiding the risks of conflict of interest, as well as the construction of complex and expensive organizational structures. Positive experience in the association of agricultural enterprises is creating financial and credit infrastructure within such a cooperation through the formation of saving funds and lending services. It is possible to achieve it by means of economies of scale due to clearly formulated one target functions. Support for such cooperation by the local population is a key element of their viability. The mechanism of functioning of the financial and credit infrastructure of support for agricultural enterprises appears in the unity of mechanisms for the functioning of its subsystems (financial and credit). The mechanisms of functioning of the financial and credit infrastructure of support for agricultural enterprises are a specific form of manifestation of its general mechanism of functioning and at the same time an integral part (Mishkin, 1999).

Each mechanism for the functioning of the financial and credit infrastructure of support for agricultural enterprises includes a functional subsystem consisting of functional elements (methods and levers), and a subsystem of ensuring the functioning of financial and credit mechanisms. Functional elements include: financial (credit) methods and financial (credit) levers that reflect the specifics of elements of the financial and credit 
infrastructure of agriculture. Elements are provided by the unifying of all mechanisms of functioning of the financial and credit infrastructure of agriculture; they create conditions for their effective work (Figure 2).

The main advantages of using agro-leasing companies are as follows: the creation and placement of a state order for the production of machinery supplied to producers of agricultural products under contracts; the opportunity for agricultural producers to transfer agricultural products as lease payments under already concluded contracts at fixed prices set by the Ministry of Agrarian Policy and Food of Ukraine at the beginning of the year, that is, on futures contracts (Onehina \& Shybaieva, 2016). The availability of these elements of financial and credit support for agricultural enterprises will contribute not only to their development but also to the expansion of entrepreneurial potential.

Approaches to providing loans and finance should be adapted to the needs of specific customers. Heterogeneous conditions and needs require a lot of approximations. In transition economies, the financial and credit infrastructure of support for agricultural enterprises is often aimed at merging small farms into large collective enterprises. Small agricultural enterprises lack information and experience to solve possible production, logistics and marketing problems. It is believed that the forma- tion of an effective financial and credit infrastructure of support for agricultural enterprises will result in an improvement of the financial provision of agricultural producers; in particular, the level of satisfaction of their needs for credit resources will increase. Optimistic and pessimistic scenarios of development of credit support of agricultural enterprises are developed (Table 3) (Agrarian Union of Ukraine, 2017).

This evolution corresponds to the importance of providing finance and credit to ensure the sustainable development of the agricultural sector. As rural populations diversify their economic activity or go out of the primary agricultural sector, rural customers will seek a full range of financial services needed by small and medium-sized customers. Further, several options for the development of financial and credit infrastructure, including restructuring of the bank, are proposed for consideration:

- initial capitalization: to solve this problem, loan applicants can contribute to the stock base of the institution and become a shareholder. This can be particularly effective if the institution develops into a cooperative banking structure;

- consolidation of existing, small autonomous institutions into the network. In such cases, a two-tier structure may be suitable;

Table 3. Expected amount of loans attracted by agricultural enterprises for the period up to the year 2020 (UAH billion)

\begin{tabular}{|c|c|c|c|c|c|c|c|c|c|}
\hline \multirow{2}{*}{ Index } & \multirow{2}{*}{2012} & \multirow{2}{*}{2013} & \multirow{2}{*}{2014} & \multirow{2}{*}{2015} & \multirow{2}{*}{2016} & \multirow{2}{*}{2017} & \multirow{2}{*}{$\begin{array}{c}\text { Total } \\
2018-2020\end{array}$} & \multicolumn{2}{|c|}{ Growth, times } \\
\hline & & & & & & & & 2017-2012 & 2020-2012 \\
\hline \multicolumn{10}{|c|}{ Optimistic scenario } \\
\hline $\begin{array}{l}\text { The volume of } \\
\text { attracted loans, total }\end{array}$ & 10.1 & 12.7 & 16.2 & 21.4 & 26.8 & 31.2 & 180.0 & 3.1 & 3.6 \\
\hline $\begin{array}{l}\text { Including privileged } \\
\text { ones }\end{array}$ & 1.4 & 3.9 & 7.5 & 11.2 & 15.4 & 19.7 & 130.0 & 14.1 & 18.6 \\
\hline \multicolumn{10}{|c|}{ From total loans: } \\
\hline Long-term & 3.1 & 3.8 & 6.1 & 9.1 & 10.6 & 13.1 & 80.0 & 4.2 & 5.2 \\
\hline Short-term & 7.0 & 8.9 & 10.1 & 12.3 & 16.2 & 18.1 & 100.0 & 2.6 & 3.0 \\
\hline \multicolumn{10}{|c|}{ Pessimistic scenario } \\
\hline $\begin{array}{l}\text { The volume of } \\
\text { attracted loans, total }\end{array}$ & 10.1 & 12.7 & 14.8 & 18.2 & 22.3 & 27.2 & 150.0 & 2.7 & 3.0 \\
\hline $\begin{array}{l}\text { Including privileged } \\
\text { ones }\end{array}$ & 1.4 & 3.9 & 5.5 & 8.6 & 13.8 & 18.1 & 100.0 & 12.9 & 14.3 \\
\hline \multicolumn{10}{|c|}{ From total loans: } \\
\hline Long-term & 3.1 & 3.8 & 5.3 & 7.4 & 9.5 & 11.1 & 50.0 & 3.6 & 4.8 \\
\hline Short-term & 7.0 & 8.9 & 9.5 & 10.8 & 12.7 & 16.1 & 100.0 & 2.3 & 2.8 \\
\hline
\end{tabular}




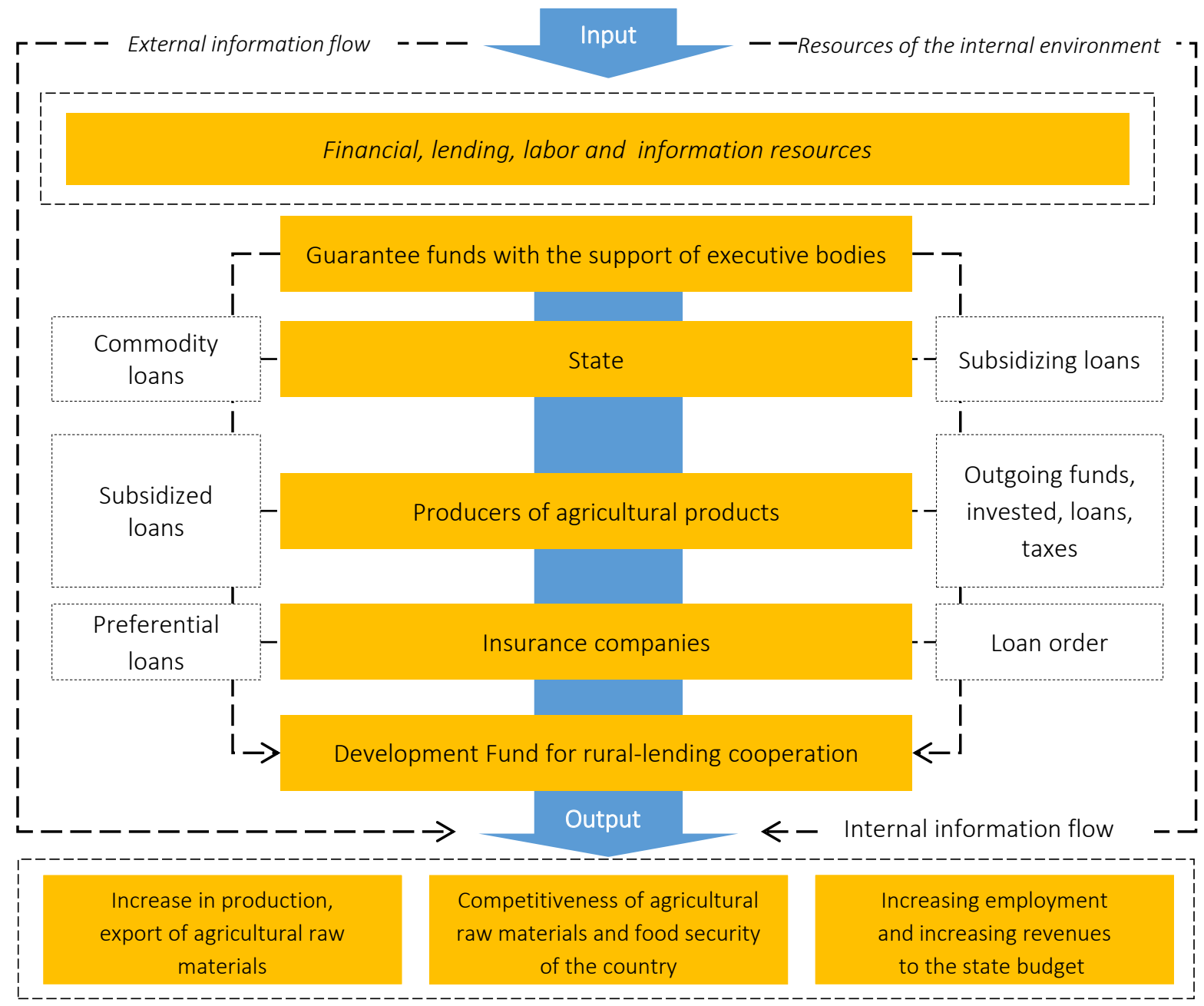

Figure 3. Model of functioning of financial and credit infrastructure of support for agricultural enterprises

- creation of a specialized unit by commercial banks for the financing of agricultural enterprises;

- privatization and restructuring of large state agricultural banks.

Increase in the availability of agricultural commodity producers can be achieved using a mechanism for the reimbursement of part of the cost of paying interest on loans received by agricultural organizations and organizations that carry out primary and further processing of agricultural products in Ukrainian lending organizations and loans received in agricultural credit consumer cooperatives.

The model of functioning of the financial and credit infrastructure of agricultural activity is presented in Figure 3.
Overcoming the mortgage base deficit could directly contribute to the development of the land mortgage lending system and the pledge of the future harvest, etc. The priority of the land-mortgage lending system development is due to the fact that agricultural land is a basic prerequisite and the foundation of manufacture in agriculture and can be in the capacity of collateral for a loan (Mrema, 2007).

Preventing the development of land-mortgage lending lies in the imperfection of legislative provision. There is no clear system of legal regulation of the land market, which does not take into account the interests of all mortgage process participants and does not allow full implementation of the functions of land mortgage. Uncertainty in the delimitation of state land ownership, the lack of properly arranged ownership of landholdings by potential borrowers not only hinder the development of land and mort- 
gage lending, but also obstruct the use of land as a pledge by the commercial banks.

The next direction of support for agricultural producers is an increase in their solvency, which is possible through financial rehabilitation, restructuring of arrears of taxes and fees. The direction of the development of the credit mechanism for the functioning of the financial and credit infrastructure of agriculture can be noted as well as the support of specialized institutions, which help to reduce credit risks. It is relevant to include support and development of guarantee funds, support of the agricultural insurance system.
Lending to agricultural producers by commercial banks is possible through the use of the mechanism of differentiated guarantees on behalf of the state. As a result, the problem of the lack of financial resources availability for most agricultural manufacturers will be solved. The next direction of development for credit mechanism of the functioning of the financial and credit infrastructure of support for agricultural enterprises includes support and development of credit institutions in order to expand the resource base of commercial banks and non-bank lending institutions, stimulation of the specialized institutions, and development of a network of lending institutions.

\section{CONCLUSION}

Features of diversification of sources of agricultural enterprises financing are elements of financial and credit infrastructure, namely: financial (requires creating a reinsurance system within the framework of the association of agricultural enterprises, which will assume risks under insurance contracts that exceeds the insurers' possibilities) and credit (includes seasonality of production and the disagreement over the time spikes in the incurrence of costs and revenue generation, in order to avoid the accumulation of debts on fines and penalties of agricultural producers). Lending through the mechanism of credit co-operation is proposed as one of the directions implementing financial and credit support of agricultural enterprises by mobilizing the savings of local population, which will solve many financial and social and economic problems of shareholders, promote formation and stimulation of agricultural entrepreneurship, increase financial stability and solvency.

The model of interaction of participants of the financial and credit infrastructure of support for agricultural enterprises through the formation of framework conditions, determination of the role of the Government and possible channels for creation of an appropriate financial and credit infrastructure of support for agricultural enterprises is offered. Proposals covering a wide range of macroeconomic, institutional and micro-level components are made. Nowadays, in many respects, the development of Ukraine's financial and credit infrastructure offers favorable prospects for access to the sources of credit, finance and investment necessary to continue the modernization of agricultural enterprises.

\section{REFERENCES}

1. Agrarian Union of Ukraine (2017). Державна підтримка аграрного сектору у 2017 poui [Derzhavna pidtrymka ahrarnoho sektoru $u$ 2017 rotsi]. Retrieved from http:// www.auu.org.ua/uk/publications/ web/206/

2. Andriushchenko, K., Rudyk, V., Riabchenko, O., Kachynska, M., Marynenko, N., Shergina, L., Kovtun, V., Tepliuk, M., Zhemba, A., \& Kuchai, O. (2019). Processes of managing information infrastructure of a digital enterprise in the framework of the "Industry 4.0" concept. Eastern-European Journal of Enterprise Technologies, 1(3), 6072. https://doi.org/10.15587/17294061.2019.157765

3. Andriushchenko, K., Shergina, L., \& Kovtun, V. (2018). Analysis of peculiarities and prospects of development of Ukraine in the concept of "Industry 4.0". Technology Audit and Production Reserves, 4(5), 36-42. https://doi.org/10.15587/23128372.2018.142354
4. Andriushchenko, K. Stefanyshyn, D., Sahaidak, M., Tepliuk, M., Buchynska, O., Rozmetova, E., Marusei, T., Levchenko, Ia., Smyrnova, I., \& Zhytomyrska, T. (2018). Process of resources provision management of the enterprise's activity with consideration of gender factor. EasternEuropean Journal of Enterprise Technologies, 6(3), 6-19. https://doi.org/10.15587/17294061.2018.150799 
5. Arbuzov, S. H. (2011).

Банківська енииклопедія [Bankivska entsyklopediia]. Tsentr naukovykh doslidzhen Natsionalnoho banku Ukrainy, Kyiv, Ukraine.

6. Campion, A. (2006). Agricultural value chain finance in Peru. Presentation at the Latin American Conference.

7. Devisy. (2017). Peculiarities of taxation of agricultural enterprises - payers of the unified tax of group IV. Retrieved from https://devisu.ua/en/stattia/osoblivosti-opodatkuvannja-silskogospodarskih-pidpriemstv--platnikivedinogo-podatku-iv-grupi

8. Dusuki, A. W. (2008). Banking for the Poor: The Role of Islamic Banking in Microfinance Initiatives. Humanomics, 24(1), 49-66. https://doi. org/10.1108/08288660810851469

9. Gonzalez-Vega, C. (2006). Modern value chains: toward the creation and strengthening of creditworthiness. In R. Quirós (Ed.), Agricultural value chain finance (pp. 45-63). San José: FAO and Academia de Centroamérica. Retrieved from http://www.fao. org/3/a-i0016e.pdf

10. Häring, A., Vairo, D., Dabbert, S., \& Zanoli, R. (2009). Organic farming policy development in the EU: What can multistakeholder processes contribute? Food Policy, 34(3), 265-272. https://doi.org/10.1016/j.foodpol.2009.03.006

11. Hudz, O. Ye. (2012). Податкове регулювання розвитку агросфери в Україні [Podatkove rehuliuvannia rozvytku ahrosfery v Ukraini]. Efektyvna ekonomika, 1. Retrieved from http:// www.economy.nayka.com. $\mathrm{ua} /$ ?op $=1 \& \mathrm{z}=880$

12. Kovyrshin, M. A. (2010). Kpeдитно-финансовая система как ключевой фактор экономического роста аграрной сферы АПК [Kreditno-finansovaya sistema kak klyuchevoy faktor ekonomicheskogo rosta agrarnoy sfery APK]. Vestnik Altayskogo gosudarstvennogo agrarnogo universiteta, 8(70),
82-88. Retrieved from https:// cyberleninka.ru/article/n/ kreditno-finansovaya-sistemakak-klyuchevoy-faktor-ekonomicheskogo-rosta-agrarnoy-sferyapk

13. Kuznets, S. (1961). Capital in the American Economy: Its Formation and Financing. NJ: Princeton Legacy Library. Retrieved from https://books. google.com.ua/books/about/ Capital_in_the_American_Economy.html?id=TVTWCgAAQ BAJ\&printsec $=$ frontcover\&so urce $=$ kp_read_button\&redir_ $\mathrm{esc}=\mathrm{y} \# \mathrm{v}=$ onepage $\& \mathrm{q} \& \mathrm{f}=$ false

14. Marangu, K. (2007). Kenya BDS program, experience in value chain facilitation. Presentation at the AFRACA Agribanks Forum.

15. Martinez, E. (2006). Banorte Banca agropecuaria. Presentation at the Latin America Conference.

16. Mathijs, E., \& Swinnen, J. (2000). Major Features of the New Farming Structures in Central and Eastern Europe. In C. Csaba \& L. Zvi (Eds.), Structural change in the farming sectors in Central and Eastern Europe: lessons for EU accession - Second World Bank/FAO Workshop, June 27-29, 1999 (World Bank Technical Paper No. 465) (pp. 22-38). Washington, D. C.: The World Bank. Retrieved from http://documents.worldbank.org/curated/ en/267151468776098706/pdf/ multi-page.pdf

17. Matselioukh, N., \& Skoryk, M. (2016). Оподаткування аграрного сектору: Проблеми і нові підходи в системі Державного регулювання [Opodatkuvannya ahrarnoho sektoru: problemy i novi pidkhody v systemi derzhavnoho rehulyuvannya]. Ahrosvit, 12, 24-28. Retrieved from http://www. agrosvit.info/pdf/12_2016/4.pdf

18. Menkyu, N. G., \& Teylor, M. (2013). Makroekonomika (560 p.). SPb: Piter.

19. Mishkin, F. S. (1999). Global Financial Instability: Framework, Events, Issues. Journal of Economic Perspectives, 13(4), 3-20. https://doi.org/10.1257/ jep.13.4.3
20. Mitrofanova, I. V. (2010). Агропромышленный комплекс Юга России: статистика кризиса [Agropromyshlennyy kompleks Yuga Rossii: statistika krizisa]. Natsionalnyye interesy: prioritety $i$ bezopasnost, 6(24), 26-38.

21. Mrema, H. (2007). Mainstreaming smallholder farmers into the world economy, using farmer ownership model. Presentation at the AFRACA Agribanks Forum.

22. Myint, K. (2007). Value chain finance. Presentation at Asia International Conference.

23. Nyoro, J. (2007). Financing agriculture: Historical perspective. Presentation at the AFRACA Agribanks Forum.

24. OECD. (2001, May). Agricultural Finance and Credit Infrastructure in Transition Economies: Focus on South Eastern Europe. Proceedings of OECD Expert Meeting. Portoroz, Slovenia.

25. Onehina, V. M., \& Shybaieva, N. V. (2016). Інституційна основа аграрної політики: українські реалії й досвід США та ЄС [Instytutsiina osnova ahrarnoi polityky: ukrainski realii y dosvid SShA ta YeS]. Ekonomika APK, 1, 18-24. Retrieved from http://nbuv. gov.ua/UJRN/E_apk_2016_1_4

26. Pleshakova, M. V., \& Drobyishev, D. S. (2005). Regionalistika (182 p.). Volgograd: VolgGTU.

27. Schinasi, G. J. (2005). Safeguarding financial stability: theory and practice. Washington, D. C.: International Monetary Fund. Retrieved from https:// www.imf.org/External/Pubs/ NFT/2005/SFS/eng/sfs.pdf

28. Shwedel, K. (2007). Value chain financing: a strategy for an orderly, competitive, integrated market. In R. Quirós (Ed.), Agricultural value chain finance (pp. 11-27). San José: FAO and Academia de Centroamérica. Retrieved from http://www.fao.org/3/a-i0016e.pdf

29. Stukach, V. F., \& Fleykler, I. A. (2007). Финансово-кредитная инфраструктура регионального АПК [Finansovo-kreditnaya 
infrastruktura regionalnogo APK] (204 p.). Omsk: Izd-vo OmGAU. Retrieved from https://elibrary.ru/ item. asp? $\mathrm{id}=20141890$

30. Tanklevska, N. S. (2011).

Розвиток податкових відносин у сільському господарстві країни [Rozvytok podatkovykh vidnosyn u silskomu hospodarstvi krainy]. Naukovyi visnyk NUBiP Ukrainy, 168(2), 337-342.

31. Willer, H., \& Kilcher, L. (Eds.) (2009). The World of Organic Agriculture. Statistics and
Emerging Trends 2009. Bonn: IFOAM; Frick: FiBL.

32. World Bank (2002). World Development Report 2002: Building Institutions for Markets. New York: Oxford University Press. Retrieved from https://openknowledge. worldbank.org/handle/10986/5984

33. World Economic Forum (2018). The Global Competitiveness Report 2017-2018. Retrieved from http://www3.weforum.org/docs/ GCR2017-2018/05FullReport/The GlobalCompetitivenessReport201 7\%E2\%80\%932018.pdf
34. Yaron, J. (1994). What makes rural finance institutions successful? The World Bank Research Observer, 9(1), 4970. https://doi.org/10.1093/ wbro/9.1.49

35. Zelisko, I. (2017). Euro integration determinants of financial support of agricultural formations competitiveness in Ukraine. Innovations in science and education: challenges of our time/collection of scientific papers. London, UK: IASHE. 